\title{
Growth Response of Nile Tilapia (Oreochromis niloticus) Fries Fed on Silage-based Diets
}

\author{
Bezuayehu Gutema Asefa ${ }^{*}$, Abelneh Yimer Melaku, Fikadu Hailemichael Tsige \\ National Fishery and Aquatic Life Research Center (NFALRC), Ethiopian Institute of Agricultural Research, Sebeta, Ethiopia \\ Email address: \\ bezuayehug7@gmail.com (B. G. Asefa) \\ ${ }^{*}$ Corresponding author \\ To cite this article: \\ Bezuayehu Gutema Asefa, Abelneh Yimer Melaku, Fikadu Hailemichael Tsige. Growth Response of Nile Tilapia (Oreochromis niloticus) \\ Fries Fed on Silage-based Diets. International Journal of Science and Qualitative Analysis. Vol. 7, No. 1, 2021, pp. $30-34$. \\ doi: $10.11648 /$ j.ijsqa.20210701.15
}

Received: April 20, 2021; Accepted: June 15, 2021; Published: June 22, 2021

\begin{abstract}
Fish silage was prepared using minced fish body leftovers by adding formic acid and formulated with other plant source ingredients. The silage making process was completed after 48 days, and incorporated into the experimental diets. The growth trial was conducted to investigate the effect of silage incorporation in the diets of Nile tilapia (Oreochromis niloticus L.) fries. Three dried diets containing (T1) $0 \%$, (T2) $20 \%$ and (T3) $30 \%$ silage were prepared with $30 \%$ crude protein and the experiment was conducted in 12 glass aquaria with a stocking density of 30 fish/aquarium for 16 weeks. Results indicated that WG, FCR, and SGR of $O$. niloticus fries fed on T2 and T3 diets were not affected $(\mathrm{p}<0.05)$ by the difference in feed. The least growth performance was recorded in $\mathrm{T} 1$ and it was significantly different $(\mathrm{P}<0.05)$ with $\mathrm{T} 2$ and $\mathrm{T} 3$. The fries fed on silage incorporation showed the best survival rate (100\%) but the fries that fed without silage had less survival rate (83.3\%). This indicates fish silage can be used as a feed for O.niloticus at an early stage. Under the present study condition, incorporation of fish silage at $20 \%$ inclusion in the diets of $O$. niloticus fries is better and further study is necessary for different inclusions.
\end{abstract}

Keywords: Silage, Growth Performance, O. niloticus, Fry Feed, Feed Conversion Ratio, Survival Rate, Fish

\section{Introduction}

Currently, aquaculture is one of the fastest growing food producing sector in the world and has succeeded as a major contributor to poverty mitigation, food security and income generation. In addition, aquaculture is an important domestic supplier of greatly desired, high quality, animal protein, generally at prices reasonable to the poorer segments of society. It is also considerable source of occupation, cash income and foreign exchange, with developing countries contributing over $90 \%$ of the total global production [1]. In many developing countries, there is a significant opportunity in order to improve aquaculture to food supplies and poverty alleviation [2]. However, according to FAO [2], aquaculture in the developing region is facing significant challenges and among those, meeting the growing demands for seed, feed, and fertilizers; in terms of quantities and quality have the highest priority. In Ethiopia, there are a number of challenges for the development of aquaculture. Among them, lack of reasonably priced and locally available quality fish feed are the major factors.

Commercially produced compound feeds are readily available for aquaculture in developed countries. In most developing countries, formulated feeds for fish are scarce or entirely unavailable [3]. Although some developing countries are importing formulated fish feeds, these are usually too expensive for economically viable fish production. Since feed costs represent $40-50 \%$ of the total variable production costs [4], locally produced and reasonably priced feedstuff of sufficient nutritional quality is a key element in the development of aquaculture in countries like Ethiopia [5]. As aquaculture production becomes more and more intensive, fish feeds will be a significant factor in increasing the productivity and profitability of the sector [6]. Because feed management determines the viability of aquaculture as it accounts for at least $40-60 \%$ of the cost of fish production $[4,6]$.

Fishing operations yield includes considerable waste materials such as by-catch fish and filleting scrap. Unfortunately, lack of processing facilities in many lesser- 
developed countries like Ethiopia often leads to the paradoxical situation of wastage occurring where the need for protein is greater. Although priority should be given to the direct use of fish for human consumption, there are often considerable quantities of fish wastes available for animal feeding. In Ethiopia, where supplies of fish waste may be small and irregular, it is uneconomical either to transport the waste to a fishmeal plant or to build a small local factory.

Fish silage may be a suitable and alternative method of preserving valuable fish wastes into animal feed in the form of powder to reduce aquaculture-production costs and increase profits. Fish silage is a liquid product produced from the whole fish or parts of it, to which acids, enzymes or lactic acid-producing bacteria are added, with the liquefaction of the mass activated by the action of enzymes from the fish. Powder fish silage can be extremely used as a feed supplement in aquaculture to convert nutrients into flesh. Because inclusions of fish silage in fish diets improve body weight gain, total body length and specific growth rate without any antagonistic effects on survival and water quality [25].

According to Backhoff [7], acid preserved fish silage is a liquid product prepared by adding acid to fish or fish waste and liquefaction is caused by proteolytic enzymes, present naturally in the fish. The addition of acid stimulates proteolysis processes, which helps in dissolving bones and prevents bacterial and fungal spoilage [8]. Moreover, aseptically prepared fish silage can replace fishmeal in the diets of fish [9]. This study aimed to evaluate the nutritive value and incorporate the waste as protein sources in the diet of O.niloticus fries.

\section{Materials and Methods}

\subsection{Experimental Units}

A total number of 360 fries of $O$. niloticus with an average initial weight of $0.4 \mathrm{~g}$ were used in this study. The fish were divided into 12 similar groups in glass aquaria $(73 \times 43 \times 35$ $\mathrm{cm})$ containing an equal amount of water (100 litters) in each, representing three dietary treatments each in four replicates. Each aquarium was supplied a circulating water one liter/minute. Water temperature was controlled thermostatically by automatic heaters and was measured two times daily using multiline probe.

\subsection{Experimental Fish}

All fish were taken from the National Fishery and Aquatic Life Research Center (NFALRC) hatchery. All fish were kept for two weeks in a fiberglass tank before their distribution into the experimental aquaria for adaptation to the new environment. The fish were then randomly divided into equal groups in the experimental aquaria (30 fish/aquarium). The fish were kept one week in the aquaria before the beginning of the experiment.

\subsection{Experimental Diets}

Fish silage was prepared using discards of O.niloticus fish, which was collected from Lake Ziway, landing sites. The leftover was collected, washed, and minced into small size. Then it was immediately treated with a $1.5 \%$ formic acid and $1.5 \%$ sulfuric acid by weight of a homogenized fish mixture [10]. Then, it was closed and transported to NFALRC laboratories. The homogenized fish mixture was stored for 48 days by mixing thoroughly once a day. The chemical analysis of the produced fish silage after 48 days storage period was reported. Before the formulation of the experimental diets, fish silage was neutralized by adding $1.6 \%$ calcium hydroxide to raise the silage $\mathrm{pH}$ from 4.1 to 5.2 . Fish silage was mixed with the other ingredients to formulate 3 diets containing, 0,20 , and $30 \%$ of fish silage (Table 1).

\subsection{Experimental Procedure}

The experiment lasted for 12 weeks after the start [11]. During the experimental period, fish were fed the experimental diets at a rate of $10 \%$ of the live body weight daily and the feed was offered twice daily at 9.0 a.m and 3.0 p.m [12]. The fish groups were weighed monthly and the amount of the feed was adjusted according to the actual body weight changes. Water samples were taken from each aquarium to determine water quality parameters. One-third of water volume was changed weekly and the whole water volume was changed every month to clean the aquaria walls and remove the attached algae.

\subsection{Proximate Analysis}

Proximate analysis for silage and experimental diets were carried out for moisture, ash, protein, and fat according to the methods described by AOAC [13]. The ingredients of the experimental diets were ground in a hammer mill and mixed. Thereafter, water was added to the mixture and made dough [12]. The composition of the experimental diets tested and the proximate analysis is shown in Table 1.

Table 1. Chemical composition and analyses of the ration.

\begin{tabular}{llll}
\hline \multirow{2}{*}{ Ingredient (\%) } & \multicolumn{3}{l}{ Rations for O.niloticus $(\%)$} \\
\cline { 2 - 4 } & T1 & T2 & T3 \\
\hline Fish Silage & 0 & 20 & 30 \\
Brewery waste & 30.8 & 30.55 & 26.59 \\
Wheat bran & 26.5 & 29.09 & 32.11 \\
Soybean & 42.7 & 20.36 & 11.3 \\
Composition & & & \\
Moisture & 2.2 & 2.49 & 2.63 \\
Crude protein & 30.0 & 30 & 30 \\
Ash & 1.1 & 2.24 & 2.79 \\
\hline
\end{tabular}

$\mathrm{T} 1=0 \%$ of silage; $\mathrm{T} 2=20 \%$ of silage; $\mathrm{T} 3=30 \%$ of silage, *expressed in: $\mathrm{g}$ $100 \mathrm{~g}-1$ of dry matter

\subsection{Growth and Feed Utilization Parameters}

Specific growth rates (SGR), feed conversion ratio (FCR) and survival rate were calculated using the following formulae [13] respectively. 


$$
\operatorname{SGR}\left(\% d a y^{-1}\right)=\left(\frac{\left.\ln W_{f}-\ln W_{i}\right)}{d t}\right) \times 100
$$

Where: $-\mathrm{W}_{\mathrm{f}}$ and $\mathrm{W}_{\mathrm{i}}$ are the final and initial body weight of the fish, respectively; $\mathrm{dt}$ is the culturing period.

$$
F C R=\frac{F i(g)}{W g(g)}
$$

Where - Fi is the amount of feed intake $(\mathrm{g})$ in a dry weight basis, Wg is Weight gain in gram $(\mathrm{g})$

$$
\text { Survival rate }(\%)=\left(\frac{N S F-N D F}{N S F}\right) \times 100
$$

Where: - NSF and NDF are the Number of stocked and dead fish during the study period, respectively and the fish weight gain was calculated by the difference between the final weight and the initial weight.

\subsection{Water Quality Parameters}

Measurement of temperature was conducted daily, while other parameters were taken every week. Samples of water were taken from each aquarium for determination of water temperature using a water thermometer, water $\mathrm{pH}$ value using a digital $\mathrm{pH}$ meter, dissolved oxygen concentration using an oxygen meter. Analysis of ammonia was conducted in the laboratory following a procedure described in Abelneh Yimer et al. [12].

\subsection{Statistical Analysis}

The obtained numerical data were statistically analyzed using SPSS version 20 for one-way analysis of variance. When the F-test result was significant, the least significant difference was calculated according to Duncan multiple range test.

\section{Results and Discussion}

\subsection{Water Quality Parameters}

The average values of water quality parameters such as; temperature dissolved oxygen (DO) $\mathrm{mg} / \mathrm{L}, \mathrm{pH}$, conductivity, and ammonia during the whole experimental period are shown in Table 2. These parameters were within the acceptable levels required for normal growth and physiological activities of Nile tilapia $[15,16]$.

Table 2. Physico-chemical values (mean) of the experimental aquaria.

\begin{tabular}{llll}
\hline \multirow{2}{*}{ Parameter } & \multicolumn{2}{l}{ Treatment } & T3 \\
\cline { 2 - 4 } & T1 & T2 & 22.70 \\
\hline Temperature $\left({ }^{\circ} \mathrm{C}\right)$ & 22.70 & 22.80 & 8.10 \\
PH & 8.10 & 8.10 & 4.06 \\
DO $(\mathrm{mg} \backslash \mathrm{L})$ & 4.70 & 4.30 & 195.50 \\
Conductivity & 194.80 & 195.50 & 0.25 \\
Ammonia $(\mathrm{mg} \backslash \mathrm{L})$ & 0.15 & 0.24 & \\
\hline
\end{tabular}

According to Kassaye Balkew [17], for optimum fish yield, water temperature, dissolved oxygen, transparency, $\mathrm{pH}$, and salinity must be kept at an optimal level compatible with fish species. Water temperature is the most crucial parameter for fish growth. If the water temperature below the critical level, fish could stop feeding and would even die. The metabolic activity and physiological functions of aquatic animals (e.g., feed utilization, feed conversion, growth rates) can be affected by the water temperature [17-20].

\subsection{Growth Response Study}

Results in Table 3 showed that the initial weight of Nile tilapia at the start of the experiment was around $0.4 \mathrm{~g}$ for all groups indicating the homogeneity of fish distribution into the experimental groups at the start of the experiment. The effect of the experimental diets on fish growth and feed utilization after 16 weeks of experimental feeding are included in Table 3. The highest growth trend was obtained with T3 followed by $\mathrm{T} 2$, but no significant difference between T2 and T3. The lowest growth response was in T1, which was no silage incorporation. The present study showed that fish silage possessed adequate nutritional value for Nile tilapia fry at lower inclusion levels, making possible addition levels of up to $20 \%$, but needs more experiment in different inclusion levels.

Table 3. Growth performance of O.niloticus fries fed on silage incorporation formulated feeds.

\begin{tabular}{llll}
\hline \multirow{2}{*}{ Growth parameter } & \multicolumn{3}{l}{ Experimental diet } \\
\cline { 2 - 4 } & T1 & T2 & T3 \\
\hline Initial weight (g) & $0.45^{\mathrm{a}}$ & $0.44^{\mathrm{a}}$ & $0.48^{\mathrm{a}}$ \\
Final weight (g) & $1.79^{\mathrm{a}}$ & $3.04^{\mathrm{b}}$ & $3.51^{\mathrm{b}}$ \\
Weight gain (g/fish) & $1.34^{\mathrm{a}}$ & $2.6^{\mathrm{b}}$ & $3.03^{\mathrm{b}}$ \\
Average daily gain (g/fish/day) & 0.015 & 0.028 & 0.034 \\
Specific growth rate\% & 1.35 & 1.89 & 1.95 \\
Feed conversion ratio (FCR) & 2.48 & 3.95 & 3.24 \\
Survival rate\% & 83.3 & 100 & 100 \\
\hline
\end{tabular}

The same letter in the same row indicates $(\mathrm{p}>0.05)$, but different letter showed $(\mathrm{p}<0.05)$, Values with the same superscript in each row are not significantly different

Fish growth performance: the FCR value of T2 diet is almost similar to T3 diet indicating that the diet with $20 \%$ acid silage and $80 \%$ wheat bran, brewery waste, and soybean meal can be safely used while preparing aquafeeds for Nile tilapia fries. However, FCR was higher as compared to other studies $[21,22]$ due to the fluctuation of water qualities during the study period (power problem). The proximate analysis indicated in (Table 1) is different from other studies. Our study showed higher protein and ash content [22]. This difference in proximate analysis values can be justified as described by Vidotti et al. [23] and Santana-Delgado et al. [24]. These researchers stated that these deviations in values of proximate analysis are due to the chemical composition of the different raw materials and nutritional values of raw materials used for acid silage preparation. The species of the fish utilized, sex of the fish, its reproductive status, and even the cut at the time of processing affect the chemical 
composition of silages.

According to Soltan and Tharwat [11], in fry and fingerling, fish feed formulation the silage inclusion level for Nile tilapia is $25 \%$ and catfish $20 \%$ level is recommended. The inclusion level for Nile tilapia is a bit higher due to a higher requirement of IAA compared to African catfish. According to other studies, these results agree with the findings of Soltan \& Tharwat, [11]. They prepared fish silage with no removal of the lipid/oil. However, the result disagrees with Haider et al. [22], who prepared fish silage by removing the excessive lipids/add antioxidants (to decrease oxidation of lipids) and they get better growth performance. During silage preparation for fish feed, removal of oil by centrifuging/adding anti-oxidants is necessary. Remove the excessive fat layers appearing on the surface of the mixture and stirring twice a day [22] and become fishy. The amount and type of acid added to the silage, for example, diets containing high proportion formic acid fish silage reduced growth performance of the fish, due to acidity of the diet, and a high proportion of free amino acids in fish silage. It has been suggested that acidity reduces diet acceptance and affects protease activity in fish guts, while free amino acids may depress fish appetite. Fish silage of the correct acidity keeps at room temperature for at least two years without putrefaction [25]. Generally, the fish growth performance (MBW, WG, SGR, FCR) was the lowest compared to other studies [22], due to the effect of water temperature.

\section{Conclusion}

The results of the present study revealed the possibility of using a $20 \%$ silage inclusion feed formulation for the growth performance and economic viability of $\mathrm{O}$. niloticus fries culture. However, one must remove the lipid content during silage preparation. In Ethiopia, there are many fish leftovers in many fish landing sites. It is a very important resource for animal feeds. The majority of the wastes are disposed of in the lakes and lead to many problems on the water bodies/environment. Therefore, further studies on the silage preparation methods need to be conducted to use as a feed ingredient for the development of fish feed.

\section{References}

[1] Subasinghe, R. P. 2003. An outlook for aquaculture development: major issues, opportunities and challenges. Review of the State of World Aquaculture, Rome Italy: FAO.

[2] FAO. 2006. State of world aquaculture (2006). FAO fisheries technical paper 500. Rome, Italy.

[3] FAO. 2003. Animal feed resources information system. Retrieved March 11, 2014 from http://www.fao.org.

[4] Craig S and LA Helfrich. 2002. Understanding fish nutrition, feeds, and feeding. Virginia cooperative extension, 63, 256270.

[5] Gabriel UU, OA Akinrotimi, DO Bekibele, DN Onunkwo, and
PE Anyanwu. 2007. Locally produced fish feed: potentials for aquaculture development in sub-Saharan Africa African Journal of Agricultural Research Vol. 2 (7), pp. 287-295.

[6] Jamu DM and OA Ayinla. 2003. Potential for the development of aquaculture in Africa. NAGA, WorldFish Center Quarterly, 26 (3), 9-13.

[7] Backhoff HP. 1976. Some chemical changes in fish silage. International Journal of Food Science \& Technology, 11 (4), 353-363.

[8] Wignall J and I Tatterson. 1976. Fish silage. Process Biochemistry, 11 (10), 17-19.

[9] Venugopal MN and P Keshavanath. 1984. Influence of supplementary feeds on the biochemical composition of flesh of freshwater carps Catlacatla (Ham.) Cirrhinusmrigala (Ham.) and Cyprinus carpio (Linn.). Indian Journal of Animal Sciences.

[10] Nabil F. Abd El-Hakim, Mahmoud O. A. Et-Gendy, Mahmoud F. I. Salem (2007). Effect of incorporation of fish silage into diets on growth performance and body composition of nile tilapia (Oreochromis niloticus), Egypt. J. Aquat. Biol \& Fish Vol. 11, No. 2: 101-11.

[11] Soltan MA and AA Tharwa. 2006. Use of fish silage for partial or complete replacement of fish meal in diets of nile tilapia (Oreochromis niloticus) and African catfish (Clarias gariepinus), Egyptian J. Nutrition and Feeds. 9 (2), 299-314.

[12] Abelneh Yimer, Adamneh Dagne, and Zenebe Tadesse. 2015. Effect of feed additives (Premix) on growth performance of Oreochromis niloticus (L. 1758.) in concert pond, SebetaEthiopia. Journal of Agricultural Research, 5 (1): 16-36.

[13] AOAC. 1990. Official Methods of Analysis, 15th edn. (Sidney Wil- liamsed). Association of Official Analytical Chemists Inc., Arlington, USA.

[14] Ridha MT. 2006. Comparative study of growth performance of three strains of Nile tilapia, Oreochromis niloticus, L. at two stocking densities. Aquac. Res., 37, 172-179.

[15] Boyd EC. 1995. Water quality in warm water fish pond. Auburn Univ. Agr. Exp. Station, Auburn, Alabama, 359 pp.

[16] Salem MF. 2006. Partial and total replacement of fishmeal by freshwater crayfish in practical diets of Nile tilapia. The 2nd International Scientific Congress for Environment, 28-30 March, South Valley Univ., Egypt.

[17] Kassaye Balkew. 2012. Evaluation of Growth Performance, Feed Utilization Efficiency and Survival Rate of Juvenile Nile tilapia, Oreochromis niloticus (Linnaeus, 1758) Reared at Different Water Temperature. J Int. Aquac., 2 (9), 59-64.

[18] Halver, J. E. \& Hardy, R. W. (2002). Fish nutrition, London, Academic Press: An imprint of Elsevier Science.

[19] Azaza MS, MN Dhraief, and MM Kraiem. 2008. Effects of water temperature on growth and sex ratio of juvenile Nile tilapia Oreochromis niloticus (Linnaeus) reared in geothermal waters in southern Tunisia. J Therm. Biol., 33, 98-105.

[20] Zenebe Tadesse, Abeba W, Mulugeta J, Fekadu T, and Fasil D. 2012, Effect of supplementary feeding of agro-industrial by products on the growth performance ofNile tilapia (Oreochromis niloticus L.) in concrete ponds, Ethiop. J. Biol. Sci., 11: 29-41. 
[21] Wassef EA. 1990. Experiments on preparation and nutritional properties of fish silage. Comm. Sci and Res., (Fac. Agric, Alexandria Univ.) 31: 143-160.

[22] Haider MS, M Ashraf, and H Azmat. 2015. Nutritional efficacy of acid fish silage in Labeo rohita at grow out stage, J. of Animal \& Plant Sciences, 25 (3): pp. 519-526.

[23] Vidotti RM, DJ Carneiro, and E Viegas. 2002. Acid and fermented silage Characterization and Determination of
Apparent Digestibility Coefficient of Crude Protein for Pacu Piaractus mesopotamicus. J. World Aquaculture Soc. 33: 57-62.

[24] Santana-Delgado H, E Avila, and A Sotelo. 2008. Preparation silage from Spanish mackerel (Scomberomorus maculates) and its evaluation in broiler diets. Anim. Feed Sci. Technol. 141:129-135.

[25] Hossain U and KMN Alam. 2015. Production of powder fish silage from fish market wastes. J. Agri., 13 (2): 13-25. 